\title{
The University and the Responsible Conduct of Research
}

\author{
Viroj Wiwanitkit
}

Received: 14 September 2010/ Accepted: 20 September 2010/Published online: 11 October 2010

(C) Springer Science+Business Media B.V. 2010

Editor, I read the recent publication on the Responsible Conduct of Research with great interest (Alfredo and Hart 2010). Alfredo and Hart explored three important groups that could be involved in research misconduct; students, advisors and universities. These three groups are responsible for research conduct outcomes. Research conduct guidelines are usually set and implemented in most universities. However, the question is whether the guidelines are properly used. Bias through using a double standard can be expected. In some situations, deans or chancellors of a university, especially in a developing country, practice misconduct. These cases are difficult to manage. How can one promote good research conduct and implement standard guidelines for everyone is a topic that should be discussed further.

\section{Reference}

Alfredo, K., \& Hart, H. (2010). The university and the responsible conduct of research: Who is responsible for what? Science and Engineering Ethics. doi:10.1007/s11948-010-9217-3.

\footnotetext{
V. Wiwanitkit $(\bowtie)$

Wiwanitkit House, Bangkhae, Bangkok 10160, Thailand e-mail:wviroj@yahoo.com
} 